\title{
ENVIRONMENTAL CORPORATE SOCIAL RESPONSIBILITY (ECSR) IN POLISH FOOD SECTOR ENTERPRISES FROM CZECSTOCHOWA REGION - EMPIRICAL ANALYSIS
}

\author{
Oksana Seroka-Stolka Ph.D. \\ Czestochowa University of Technology, \\ Faculty of Management, Al. Armii Krajowej 19b, 42-200 Czestochowa, Poland \\ e-mail: oksanas@zim.pcz.pl
}

\begin{abstract}
The purpose of the paper is the assessment of implementation of Environmental Corporate Social Responsibility (ECSR) concept in Polish food industry in Czestochowa region. ECSR is an important part of the concept of corporate social responsibility (CSR). The food industry has many impacts on the environment and strongly depends on natural resources, that is why companies' environmental consequences of their functioning are important part of corporate management.

The most popular activities in the area of the CSR in Polish enterprises relate to the environmental protection. The analysis of the research results indicates, that $38 \%$ of the surveyed enterprises follow the ECSR rules, including mostly large manufacturing enterprises. The ECSR is seen as a tool for creating positive image and reputation of a company on the market and for enhancing the organizational culture of an enterprise. Unfortunately, surveyed enterprises have not perceived the ECSR concept as a tool for creating a competitive advantage on the market yet.
\end{abstract}

Keywords: ECSR, enterprise, food sector, environment, responsibility

\section{Introduction}

All sectors of the economy are affected by the increasing societal demand with respect to CSR. However, given the characteristics of the industry, the pressure exerted on companies to take up CSR likely differs, for example with the sectors' economic, social and economic impact. While there are sectors such as mining that have a stronger impact on the environment there is likely no other sector that is as highly dependent on natural resources as the food sector while at the same time having considerable and diverse impacts on the environment (Hartmann 2011). Polish food industry enterprises with the specificity of individual sectors represent a source of a number of threats to all the components of the natural environment in: soil and water, air, plants, animals and humans.

Environmental protection in the food industry should encompass almost all its resources. Rational water and wastewater management, waste management (with particular focus on the organic waste), air and soil protection from pollutants and noise protection should be a priority in implementation of the strategies that limit the negative effect of the enterprises in the food industry on the environment.
Civil society and media increasingly request companies to consider the social and environmental consequences of their activities and to provide more transparency and openness with respect to their action (Freeman et al., 2010). Thus, it is not surprising that CSR has developed to one of the top priorities of businesses over the last decade. In the context of CSR the food sector faces specific challenges. That is why Polish food companies can be more responsible and transparent via implementation of the Environmental Corporate Social Responsibility (ECSR) concept.

\section{Terminology of the ECSR concept}

Environmental corporate social responsibility (ECSR) is an important and distinct part of the overarching concept of corporate social responsibility (CSR). Strategies related to environmental aspects mainly concern the reduction and recycling of resources. The environmental dimension of CSR engagement is concerned with the following environmental indicators that could be approached separately or combined. Strategies on biodiversity are on the protection of the regional environment and support for biodiverse areas. Emission is on the reduction of greenhouse gas emissions within the 
production process. The dimension energy and water concerns the reduction of energy demand of the company. Resource consumption/material efficiency is approaching the recycling and re-usage of material within the production processes. This is related to waste disposal that is concerning correct separation of waste for recycling.

High levels of CSR do not necessarily equate to high levels of ECSR. ECSR is a multidimensional concept (Rahman and Post 2012). According to Mazurkiewicz ECSR is "the duty to cover the environmental implications of the company's operations, products and facilities; eliminate waste and emissions; maximize the efficiency and productivity of its resources; and minimize practices that might adversely affect the enjoyment of the country's resources by future generations" (Mazurkiewicz 2004). Others have defined ECSR as environmentally friendly actions that go beyond the compliance of legal requirements by privately providing for public goods or internalizing negative externalities (Lyon and Maxwell 2008; Portney 2008). ECSR is a concept of companies voluntarily integrating environmental concerns in their business operations and in their interaction with their stakeholders. It is viewed as the contribution that firms make to sustainable development by balancing and improving environmental impacts without damaging economic performance (Lyon and Maxwell 2008). Corporate ecological responsiveness is a set of corporate initiatives aimed at mitigating a firm's impact on the natural environment. These initiatives can include changes to the firm's products, processes, and policies, such as reducing energy consumption and waste generation, using ecologically sustainable resources, and implementing an environmental management system. The concept of corporate ecological responsiveness refers not to what a firm should do, but to the initiatives that reduce the firm's 'ecological footprint' (Bansal and Roth 2000). Broadly, ECSR focuses on firm-specific activities, both compliant and preventative, that limit the adverse environmental impact of these firms.

\section{Benefits of the implementation of the ECSR instrument in enterprises}

Organizations operating in accordance with the environmental corporate responsibility can benefit in multiple ways both external related to the company's environment and internal representing the relations within the company itself. Another approach to classifying benefits of the ECSR implementation is to divide them into general business, operational and financial.

The first group of general business benefits include mainly the improvement of company's reputation and enhancing the brand capital through environmentally-friendly behaviour. The brand capital and brand value must be created by all interested parties satisfied with their expectations, and not only by customers (Chi-Shiun Lai et. al., 2010). Environmental corporate responsibility can contribute to the establishment of new businesses and to the improvement of relations with interested parties, especially with local communities. Enterprises' engagement and its commitment to solve environmental problems make obtaining the local communities favour easier, help to win local authorities' trust, and to reduce the frequency of interventions by regulators.

The second group of the operational benefits resulting from following the ECSR idea include: quality improvement and innovation increase (including eco-innovation), increase of loyalty not only of employees but also customers and contractors. Higher environmental quality of products accompanied by affordable price for consumers can contribute to the increase of sales to aware customers and interested parties. The implementation of environmental good practices often leads to a reduction of environmental risks related to possible environmental threats.

Lowering the consumption of natural resources, reducing the emission and waste generation lead to the increase of company's eco-efficiency and value (Al Najjar and Anfimiadou 2012). Improving an enterprises' eco-efficiency helps to lower the costs and gain a competitive advantage, and is certainly one of the most emphasized financial benefits for the enterprise (Wagner 2009). The survey of the largest companies indicates that the strongest engagement in the CSR area relates to the environmental protection (Menedżerowie 500).

The positive effect of the ECSR can also be assessed not only from the point of view of financial performance but also non-financial performance, which are related to the creation of the image and reputation of an organization, to the increase of employee motivation, and to the improvement of brand image mentioned before (Chodyński 2011). Enterprises that demonstrate environmental proactivity in the area of environmental corporate responsibility benefit through the increased sales to customers who appreciate environmentallyfriendly attitudes and behaviour, thus increasing their revenues.

\section{Materials and methods}

The research was conducted in years 2011-2012 on a sample of 33 enterprises representing small (16\%), mediumsized (29\%), and large (55\%) enterprises from food industry in $\mathrm{Cz}$ stochowa region ${ }^{1}$. Covered by the research were the enterprises from following sectors: services (5\%), trade (20\%), manufacturing (38\%), and multisectoral (37\%). As far as industry was concerned the sample was dominated by dairy, fruit and vegetable, bakery and meat enterprises. The questionnaire was filled by entrepreneurs ${ }^{2}$ or managers. The random selection was used. Surveyed subjects were enterprises of worldwide (20\%), European (48\%), and national (32\%) range. The financial standing of surveyed enterprises in the sample was as follows: very good (16\%), good (43\%), average $(33 \%)$, and poor $(8 \%)$. Gathered statistical data were

In Częstochowa region there are 49,713 registered enterprises (as of 31.12.2011), including 48,371 privately owned enterprises.

2In small and medium-sized companies. 
processed with STATISTICA 9.1 software both in terms of quantity and quality with the use of descriptive statistics and Spearman's rank correlation coefficient.

The first question was whether the respondents in their activity take into account the Environmental Corporate Social Responsibility idea. The group of enterprises that follow the ECSR rules was asked to indicate the activities that they implement in the ECSR area (Figure 1). Then the respondents were asked to comment on two sets of statements related to the external and internal benefits that can be obtained by enterprises that follow the ECSR idea (those statements are presented in Tables 1 and 2). Respondents answered the questions with the replies prepared on the 5-point Likert scale.

\section{Results and discussion}

The quantitative analysis indicates that $38 \%$ enterprises of the sample follow the ECSR rules, of which $28.6 \%$ of surveyed were large manufacturing enterprises. This group included companies of good or very good financial standing and operating in the worldwide range. 9\% of surveyed enterprises do not follow any ECSR rules in their business activity. Other enterprises answered the question with "rather yes" (50\%), "rather no" and "do not know" (7.14\%). Total of $14.3 \%$ of surveyed enterprises are not decided in the matter of the ECSR implementation in their organizations.

Further in the survey the respondents were asked to choose presented activities in the area of CSR related to the environment. In the environment area, companies perceive the CSR mainly as the reduction of waste generation, recycling, disposal and segregation of waste (48\% of responses). The second activity significant for the surveyed in the ECSR area is the sustainable use of natural resources through efficient use of such resources as energy and water (38\% of responses). In much lesser degree the surveyed implement activities in the area of the ECSR related to counteracting climate change, biodiversity, and restoration of natural habitats. The distribution of responses is presented in Figure 1.

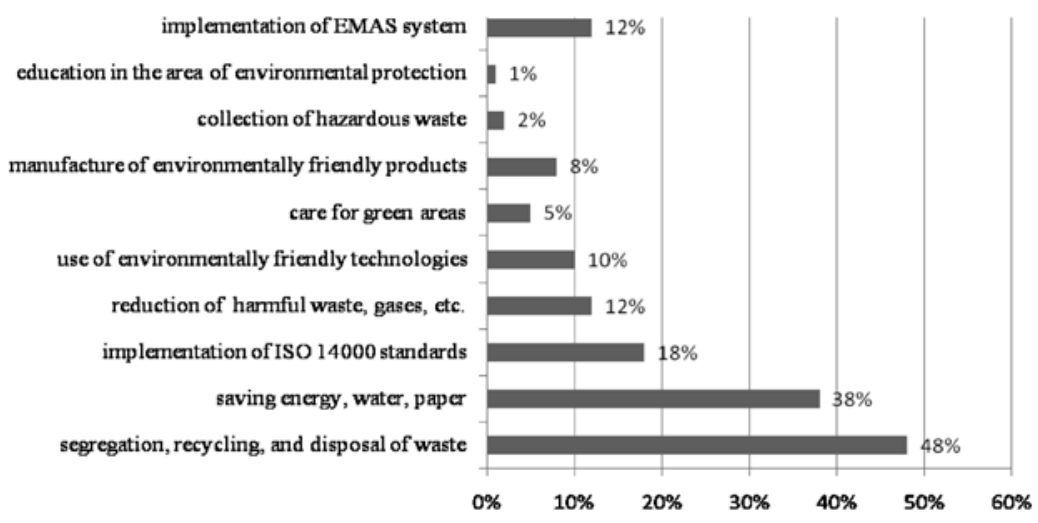

Figure 1: Activities implemented by enterprises in the area of environment within the framework of CSR concept

Responses do not sum up to 100 , as the respondents could choose more than one response Source: Own elaboration based on the research.
The second part of the research employed the qualitative analysis of studied variables, which were the attributes of possible internal benefits obtained by enterprises in result of implementing the procedure rules in accordance with the ECSR concept. The descriptive statistics analysis indicates that increasing the level of organizational culture in a company $(\bar{x}-4,16)$ is one of the most important internal benefits resulting from the ECSR implementation, in the opinion of surveyed enterprises. Compatibility of the surveyed in the assessment of this variable is high, which is demonstrated by the smallest span of responses and the lowest standard deviation. In the second place the respondents choose the improvement of management quality through the increase of products and services quality $(\bar{x}-4,08)$ and the possibility of a better compliance with legal requirements of the implementation of environmental corporate responsibility $(\bar{x}-4,04)$. Descriptive statistics for the evaluation of internal benefits of the ECSR concept are presented in Table 1 .

Table 1: Descriptive statistics for internal benefits resulting from the implementation of the ECSR in an enterprise

\begin{tabular}{|l|c|c|c|c|c|c|}
\hline & $\bar{x}$ & Mode & Median & $\begin{array}{c}\text { Standard } \\
\text { deviation }\end{array}$ & Min & Max \\
\hline $\begin{array}{l}\text { Increasing the level of } \\
\text { organizational culture }\end{array}$ & 4.16 & 4 & 4.00 & 0.66 & 3 & 5.00 \\
\hline Increasing sales & 2.96 & 3 & 3.00 & 1.10 & 1 & 5.00 \\
\hline Decreasing costs & 3.12 & 2 & 3.00 & 1.30 & 1 & 5.00 \\
\hline $\begin{array}{l}\text { Attracting and retain- } \\
\text { ing the best employees }\end{array}$ & 2.80 & 3 & 3.00 & 1.12 & 1 & 5.00 \\
\hline $\begin{array}{l}\text { Better compliance with } \\
\text { legal rules }\end{array}$ & 4.04 & 4 & 4.00 & 0.84 & 1 & 5.00 \\
\hline $\begin{array}{l}\text { Improving manage- } \\
\text { ment quality (improv- } \\
\text { ing products and } \\
\text { services quality) }\end{array}$ & 4.08 & 4 & 4.00 & 0.81 & 3 & 5.00 \\
\hline
\end{tabular}

Source: Own elaboration. Where: 1 - definitely no, 2 - rather no, 3 - do not know, 4 - rather yes, 5 - definitely yes.

The comparison of average assessments of external benefits of the ECSR implementation clearly indicate that the improvement of company's image and reputation on the market is the most important of them $(\bar{x}-4,51)$. Respondents also recognize the possibilities to make better contacts with local communities $((\bar{x}-3,75)$, however they are not consistent in that assessment (the highest standard deviation and the span of responses). Descriptive statistics for external benefits of the ECSR are presented in Table 2.

To assess the correlation relationship between the variables representing the internal and external benefits the Spearman rank correlation matrix was developed, and its results of statistically significant coefficients are presented in Table 3. 
Table 2: Descriptive statistics for external benefits resulting from the implementation of the ECSR in an enterprise

\begin{tabular}{|l|c|c|c|c|c|c|}
\hline & $\bar{x}$ & Mode & Median & $\begin{array}{c}\text { Standard } \\
\text { deviation }\end{array}$ & Min & Max \\
\hline $\begin{array}{l}\text { Improving company's im- } \\
\text { age and reputation }\end{array}$ & 4.51 & 5 & 5.00 & 0.714 & 3 & 5 \\
\hline $\begin{array}{l}\text { Increasing the loyalty of } \\
\text { customers }\end{array}$ & 3.38 & 4 & 3.50 & 0.924 & 1 & 5 \\
\hline $\begin{array}{l}\text { Increasing the chance for } \\
\text { a company's long-term } \\
\text { success }\end{array}$ & 3.40 & 4 & 3.00 & 1.080 & 1 & 5 \\
\hline $\begin{array}{l}\text { Good contacts with the } \\
\text { media }\end{array}$ & 3.04 & 4 & 3.00 & 0.955 & 1 & 4 \\
\hline $\begin{array}{l}\text { Better conditions for the } \\
\text { business }\end{array}$ & 3.00 & 3 & 3.00 & 0.957 & 1 & 5 \\
\hline $\begin{array}{l}\text { Better contacts with local } \\
\text { communities (interested } \\
\text { parties) }\end{array}$ & 3.75 & 4 & 4.00 & 1.113 & 1 & 5 \\
\hline
\end{tabular}

Source: Own elaboration. Where: 1 - definitely no, 2 - rather no, 3 - do not know, 4 - rather yes, 5 - definitely yes.

The correlation matrix shows that attracting and retaining the best employees with high competence is closely related to the increase of sales in a company (variables "attracting and retaining the best employees" vs. "increasing sales" (R -0.63 with $\mathrm{p}<0.001)$. Better compliance with legal rules in enterprises is positively correlated with improving company's image and reputation $(\mathrm{R}-0.45$ with $\mathrm{p}<0.05)$ and with company's long-term success on the market $(\mathrm{R}-0.5$ with $\mathrm{p}<0.05$ ). Developing good relations with local communities has a positive effect on the improvement of company's image and reputation ( $R-0.47$ with $p<0.05)$, on the company's longterm success $(\mathrm{R}-0.46$ with $\mathrm{p}<0.05)$, and also on the good contacts with the media $(\mathrm{R}-0.43$ with $\mathrm{p}<0.05)$.

The results of the correlation matrix give the conclusion that the continuous improvement of management quality in the enterprise contributes to increased customer loyalty ( $R$ -0.46 with $\mathrm{p}<0.05)$ and has a positively effect on a better adaption to the legal requirements $(\mathrm{R}-0.46$ with $\mathrm{p}<0.05)$. Improving the company's image and reputation has a positive effect on increasing customer loyalty $(\mathrm{R}-0.46$ with $\mathrm{p}<0.05)$.

In summary, respondents rate higher external benefits resulting from the implementation of the ECSR, regardless of the type and range of the company's business. Only companies with average financial condition and medium size assessed internal benefits from the implementation of ECSR higher.

Facing the challenges of environmental corporate responsibility helps to raise the standards of dealing with internal interested parties, which result in increased environmental culture of the company and employees better understand the rules of environmental responsibility.

Environmental programs implemented under the ECSR help to protect the natural environment and contribute to the improvement of its condition and to the pollution level reduction. The research results confirm that the most powerful motivator for activities of environmental and social responsibility is the improvement of reputation, trust and strengthening of brand capital (Marcinkowska 2010, Mishra and Suar 2010). Companies in the region also perceive the role of the media in creating a positive image and the impact of local community pressure on environmental issues. Unfortunately Polish food industry companies in the region do not treat the ECSR as a tool to improve the competitive position, despite the fact that more and more companies achieve competitive advantage and economic benefits operating in accordance with the principles of environmental responsibility (Hart and Ahuja 1997). Similarly, ecologically friendly products, processes and management systems generate benefits by increasing revenues and reducing costs. It can be observed that customers are interested in companies that demonstrate environmental proactivity (Mishra and Suar 2010). Most of the surveyed

Table 3. Internal and external benefits resulting from the implementation of the ECSR - Spearman rank correlation matrix

\begin{tabular}{|c|c|c|c|c|c|c|c|c|c|c|c|c|}
\hline & 1 & 2 & 3 & 4 & 5 & 6 & 7 & 8 & 9 & 10 & 11 & 12 \\
\hline Increasing the level of organizational culture & 1 & & & & & & & & & & & \\
\hline Increasing sales & -0.08 & 1 & & & & & & & & & & \\
\hline Decreasing costs & 0.03 & 0.23 & 1 & & & & & & & & & \\
\hline Attracting and retaining the best employees & 0.28 & $0.63 * * *$ & 0.30 & 1 & & & & & & & & \\
\hline Better compliance with legal rules & 0.28 & 0.16 & -0.14 & 0.32 & 1 & & & & & & & \\
\hline $\begin{array}{l}\text { Improving management quality (improving } \\
\text { products and services quality) }\end{array}$ & 0.35 & 0.32 & -0.09 & $0.40 *$ & $0.41 *$ & 1 & & & & & & \\
\hline Improving company's image and reputation & -0.06 & 0.27 & -0.33 & 0.24 & $0.45 *$ & 0.39 & 1 & & & & & \\
\hline Increasing the loyalty of customers & 0.08 & 0.28 & -0.08 & 0.23 & 0.31 & $0.46^{*}$ & $0.46^{*}$ & 1 & & & & \\
\hline $\begin{array}{l}\text { Increasing the chance for a company's } \\
\text { long-term success }\end{array}$ & 0.29 & 0.13 & 0.14 & $0.43^{*}$ & $0.50 *$ & 0.27 & 0.36 & 0.40 & 1 & & & \\
\hline Good contacts with the media & 0.01 & 0.36 & 0.02 & 0.26 & 0.09 & 0.19 & $0.41 *$ & $0.44 *$ & 0.25 & 1 & & \\
\hline Better conditions for the business & 0.38 & 0.12 & 0.20 & 0.24 & 0.17 & 0.35 & 0.04 & -0.05 & 0.28 & $0.43^{*}$ & 1 & \\
\hline $\begin{array}{l}\text { Better contacts with local communities } \\
\text { (interested parties) }\end{array}$ & 0.05 & 0.06 & -0.24 & 0.18 & $0.45^{*}$ & 0.36 & $0.47 *$ & 0.29 & $0.46^{*}$ & $0.43^{*}$ & 0.34 & 1 \\
\hline
\end{tabular}

Asterix indicates only the statistically significant correlation results with various significance levels $* \mathrm{p}<0.05 ; * * * \mathrm{p}<0.001$.

Source: Own elaboration. 
enterprises could not clearly determine whether they followed the ECSR standards, which may indicate a misunderstanding of the concept of the ECSR due to multiple interpretations.

\section{Summary}

In the modern economy, dynamically changing environment affects the methods and concepts of corporate management. These changes are also manifested by increasing social and environmental requirements for enterprises, especially those with significant impact on the natural environment. The activities of the food industry enterprises greatly depend on the availability of natural resources. (Environmental) quality of products and services of the food industry companies can determine the success of the market. Implementing the principles of environmental responsibility in accordance with the ECSR concept helps to improve the reputation and image of the enterprise, which may consequently contribute to its long-term success. Therefore the operation of enterprises in the modern economy is of multidimensional nature and the purpose of their activity is no longer only the maximization of profits, but also actions that require a holistic approach to corporate management.

\section{References}

Al Najjar B., Anfimiadou A. (2012): Environmental Policies and Firm Value. Business Strategy and the Environment, Business Strategy and the Environment, Vol. 21, p. 49-59.

Bansal, P., Roth K. (2000): Why Companies Go Green: A Model of Ecological Responsiveness. Academy of Management Journal, 43(4), p. 717-736.

Chi-Shiun Lai, Chih-Jen Chiu, Chin-Fang Yang, Da-Chang Pai (2010): The effect of corporate social responsibility on Brand performance: The mediating effect of industrial Brand equity and corporate reputation, Journal of Business Ethics, Vol. 95, Number $\underline{3}$, p. 457-469.

Chodyński A. (2011): Odpowiedzialność ekologiczna w proaktywnym rozwoju przedsiębiorstwa, Krakowskie Towarzystwo Edukacyjne, Kraków, p. 53.

Freeman, R. E., Harrison, J. S., Wicks, A. C., Parmar, B. L. and De Colle, S. (eds) (2010): Stakeholder Theory. The State of the Art. Cambridge, UK: Cambridge University Press.

Hart S. L., Ahuja, G. (1997): Does it pay to be green? Business Strategy and the Environment, Vol. 5, p. 31-37.

Hartmann M. (2011): Corporate social responsibility in the food sector, European Review of Agricultural Economics, Vol 38 (3), p. 297-324.

Lyon, T. P., Maxwell, J. W. (2008): Corporate social responsibility and the environment: A theoretical perspective. Review of Environmental Economics and Policy, 2(2), p. 240-260.

Marcinkowska M. (2010): Społeczna odpowiedzialność przedsiębiorstw a ich wyniki ekonomiczne - aspekty teoretyczne. Przegląd Organizacji, no 10, p. 7-10.

Mazurkiewicz, P. (2004). Corporate environmental responsibility: Is a common CSR framework possible? World Bank working paper, p. 2.

Menedżerowie 500 i odpowiedzialny biznes. Wiedza - postawy praktyka. Forum Odpowiedzialnego Biznesu, Warszawa 2003.

Mishra S., Suar D. (2010): Does Corporate Social Responsibility Influence Firm Performance of Indian Companies? Journal of Business Ethics, Vol. 95, p. 571-601.

Portney, P. R. (2008): The (Not So) new corporate social responsibility: An empirical perspective. Review of Environmental Economics and Policy, 2(2), p. 261-275.

Rahman N., Post C. (2012): Measurement Issues in Environmental Corporate Social Responsibility (ECSR): Toward a Transparent, Reliable, and Construct Valid Instrument. Journal of Business Ethics, Vol. 105, p. 307-319.

Wagner M. (2009): Innovation and competitive advantages from the integration of strategic aspects with social and environmental management in European firms. Business Strategy and the Environment, Vol.18, Issue 5,.p. 291-306. 
